Hailin, Q., \& Jingxu, Z. (2019). Can Mandatory Dividend Policy Reduce the Agency Cost of Listed Companies? Model Analysis and Empirical Test in China. Copernican Journal of Finance \& Accounting, 8(1), 59-101. http://dx.doi.org/10.12775/CJFA.2019.003

\author{
QIn HaILIN*
}

Tianjin Polytechnic University

\author{
ZHANG JINGXU** \\ Tianjin Polytechnic University
}

\title{
CAN MANDATORY DIVIDEND POLICY REDUCE THE AGENCY COST OF LISTED COMPANIES? \\ MODEL ANALYSIS AND EMPIRICAL TEST IN CHINA
}

Keywords: mandatory dividend, agency cost, dividend policy, mixed strategy equilibrium, difference-in-difference model.

\section{J E L Classification: G3.}

Abstract: In this research, the mixed strategy complete information static game was adopted to explain the effect of mandatory dividend policy on agency cost, and Chinese mandatory dividend policy introduced in 2011was regarded as the institutional background, and whether mandatory dividend policy can reduce the agency cost of listed companies as an accidental impact was studied. Empirical test indicates that mandatory dividend policy significantly inhibits the agency cost of enterprises. Further research finds that the mandatory dividend policy has a better effect on reducing agency co-

Date of submission: June 6, 2019; date of acceptance: June 11, 2019.

* Contact information: hantag@sina.com, Department of Finance, School of Economics and Management, Tianjin Polytechnic University, China 300387, phone: 022-83956738; ORCID ID: https://orcid.org/0000-0001-7792-3119.

** Contact information: 592549106@qq.com, Department of Finance, School of Economics and Management, Tianjin Polytechnic University, China 300387, phone: 022-83956738; ORCID ID: https://orcid.org/0000-0002-5497-0227. 
sts for the companies listed on the main board and those with normal dividends, while it has no significant effect on restraining agency costs for the companies with micro-dividends and small and medium-sized boards. The study supports the dividend agency cost theory and provides empirical evidence for the regulating departments to improve the follow-up policy of capital market governance.

\section{INTRODUCTION}

On November 9, 2011, Guo Shuqing, the chairman of China Securities Regulatory Commission (CSRC), clearly required listed companies to pay the dividends. This is a counterattack against those not to pay for a long time in China, however, can agency costs be significantly restrained in corporate governance?

Although it is the main purpose of mandatory dividend policy protecting the interests of small and medium investors, and has a greater impact on corporate governance, because in theory, agency costs will be lower by reducing the free cash flow of enterprises. Then, cash flow will be richer with better operating performance and stronger financial strength, on the other hand, in the property rights system arrangement, which separates ownership and management rights, although the division of labor according to comparative advantages improves the operating efficiency of enterprises, this division of labor will also objectively lead to the goal bias of owners and operators. The serious paradox is that the managers always acts according to the maximization of his own interests rather than that of shareholders' interests, such as maximizing private benefits through on-the-job consumption and related transactions, resulting in the accelerated rise of agency costs. Supposing a company with lots of cash, the profligacy and abuse of funds will be stimulated to increase of agency costs. Since the existence of free cash flow will increase the agency cost of corporate governance, reducing the free cash flow that can be controlled by executives will naturally restrain the agency cost. However, the perfection of theoretical logic does not necessarily mean the same result of capital market.

\section{THE RESEARCH METHODOLOGY AND THE COURSE OF THE RESEARCH PROCESS}

To test the implementation effect of the mandatory dividend policy, this paper intends to use the difference-in-difference model (DID) to examine the exogenous mandatory dividend impact on agency cost. Specifically, this paper regards the mandatory dividend policy of November 2011 as an exogenous shock, and studies the relation between agency cost and mandatory dividend policy. 
A-share listed companies are selected as research samples from 2007 to 2017, and the impact of mandatory dividend policy on agency cost will be examined by panel data regression model, intermediary utility model and DID model.

The possible contributions of this paper are: (1) Using a mixed strategy complete information static model, we not only skillfully incorporate the policy variable of mandatory dividend into the game model, but also explain the mechanism of mandatory dividend policy to reduce the agency cost of listed companies based on the model conclusion of mixed strategy Nash Equilibrium; (2) Using the A-share data of Shanghai and Shenzhen Stock Exchanges, we confirm the validity of the mandatory dividend policy, that is, cash dividend has a significant restraining effect on agency cost of listed companies; (3) Using difference-indifference model (DID) to overcome the endogenous problem of empirical model, strictly and effectively prove that cash dividend significantly improves corporate governance structure.

\section{LITERATURE REVIEW}

Dividend policy remains one of important research topics in corporate finance. Miller and Modigliani (1961) demonstrate that in the absence of transaction costs, dividend payment does not affect firm value, and investment policy is irrelevant to cash dividends. However, the premise of this model is very strict, that is, the capital market of perfect competition, and from this, it is deduced that the value of the enterprise is related to the present value of cash flow generated by the company in the future, and has nothing to do with dividend policy. However, there are various kinds of frictions in the operation of the capital market, and transaction costs are everywhere. Therefore, the theoretical significance of the dividend irrelevance theory is far greater than the practical implication. This will inevitably lead to imperfection of capital market, so dividend policy is decisive instead of indispensable and insignificant in the capital market with asymmetric information, free-ride phenomenon in shareholder supervision, and opportunistic behavior of controlling shareholders, adverse-selection of management, moral hazard and limited rationality of supervision departments.

\section{Cash Dividend and Agency Policy}

Existing studies largely focus on two aspects of dividend policy, some scholars believe that cash dividend will reduce agency costs and improve corporate gov- 
ernance, while others insist that dividend policy is one of the important means for large shareholders to eat up listed companies.

The first view is that cash dividend can improve firm value by reducing the agency cost. Based on dividend model and income model, it can be inferred that cash dividend is the source of the intrinsic value of stocks. Yang Hanming (2008) used the data of manufacturing industry to find that compared with other industries, the market value and dividend policy of enterprises in manufacturing industry increased synchronously. Hu Yaoting and Mahong (2017) show that the difference of agency cost will affect the relationship between cash dividend and corporate value. If there is a good governance mechanism to reduce agency cost, the cash dividend effect will be greatly reduced in corporate value. It has a significant positive correlation between cash dividend and corporate value offered by listed companies. Liu Yinguo, Zhang Chen and Ruan Sumei (2014) examined that dividend policy can reduce agency costs through free cash flow. Liu Xing, Tan Weirong and Li Ning (2016) believed that companies with strong corporate governance structure had a positive effect on dividend distribution behavior, which significantly increased the willingness of companies to pay dividends in the capital market, and to a certain extent reduced the agency conflict between the company insiders and external investors. Wei Zhihua, Li Changqing, Wu Yuhui and Huang Jiajia (2017) found that cash dividend can reduce both the first agency cost and the second Agency cost. Xu Haoran and Liao Guanmin (2018) investigated the market reaction of Chinese central state-owned enterprises (SOEs) to the mandatory dividend policy on the policy of "the return of state-owned capital handed over by Chinese central SOEs "by the Ministry of Finance, and found that the firms concerned with higher agency costs had more positive market reaction.

The second view is that dividend policy is more likely to be one of the important means for large shareholders to hollow out listed companies through the "tunnel effect". As a result, some companies with poor performance often pay large dividends and damage the value of the company. Qiang Guolin (2014) found that many listed companies have abnormal phenomena of "cash dividend paying while equity refinancing". It shows that cash dividend is the way of large shareholders to tunneling listed companies, so dividend is essentially a tunneling behavior. Qiang Guolin, Li Biao and Zhang Ziwei (2017) found that the huger amount of over-raised funds, the larger proportion of controlling shareholders, the higher the cash dividend payout. The empirical results of Xiao Zuoping and Su Zhongqin (2012) show that cash flow right is negatively 
correlated with cash dividend level, while the separation of control right and cash flow right is positively correlated with cash dividend level, indicating that shareholders regard cash dividend policy as a cover for "hollowing out". Zhu Tao and Wang Deyou (2007) studied the data of Listed Companies in 2003, and found that the actual controlling shareholders have a significant impact on dividend policy. The higher the rights of major shareholders, the more likely they are to pay cash dividends, which supports the exploitation hypothesis of large shareholders. Huang Juanjuan and Shen Yifeng (2007) found that the dividend payment of Listed Companies in our country deviates from the preferences of circulating shareholders, and the dividend policy is formulated only to cater to the large shareholders to hollow out the listed companies.

In a word, there are two opposite ideas in the empirical test of dividend and agency theory: one is that dividend policy has "tunnel effect" and is a means for large shareholders to embezzle small and medium shareholders, so dividend policy does not play a role; the other is that dividend policy effectively improves corporate governance mechanism by reducing managers' disposable cash flow. The basic economic logic of the latter is that dividend policy not only reduces managers 'on-the-job consumption and investment in projects with negative NPV, and inhibits managers' over-investment, but also plays the role of introducing third-party supervision. That is to say, because cash dividend decrease the free cash flow of enterprises in need of capital investment, third-party supervision must be introduce in refinancing. Therefore, this will ease the conflicts between managers and shareholders, large shareholders and small and medium shareholders, and restrain the resulting agency costs.

\section{Semi-mandatory dividend policy and mandatory dividend policy}

Considering that, the CSRC will promote the mandatory dividend to protect the interests of small and medium-sized investors, thereby reducing disposable cash flow and restraining agency costs.

In 2006, Measures for Securities Issue requires that the percentage of cash dividends be no less than $20 \%$ of the average annual distributable profits in the late three years by the CSRC. In 2008, the CSRC announced a stipulation titled "Decision on Revising Some Provisions on Cash Dividend Payments of Listed Companies" for refinancing companies to distribute a cumulative dividend of no less than $30 \%$ of the annual average distributable profit in the past three years. The above policy links dividend distribution with refinancing, but 
it has not achieved the desired results. Wei Zhihua, Li Changqing, Wu Yuhui and Huang Jiajia (2017) investigated that the semi-compulsory dividend policy significantly increased the willingness and level of cash dividend payout of listed companies with refinancing motivation, and the phenomenon of catering to the policy for financing appeared. Therefore, on November 9, 2011, after Guo Shuqing took office, forced enterprises to pay out.

For CSRC semi-mandatory dividend policy, one argues that it does not protect the interests of investors and listed companies as well as improve the level of corporate governance effectively. Li Changqing, Wei Zhihua and Wu Shinong (2010) used the event study method to find that for investors, the dividend policy did not bring the expected market response, and there may be a "regulatory paradox" limitation. Chen Yunling (2014) examiend that the introduction of dividend policy did not make cash-rich companies pay more dividends. On the contrary, when there is refinancing demand, companies pay more dividends, which fails to protect the interests of investors. Therefore, the rationality of the policy has been questioned. Yu Guojie and Zhao Yuyu (2018) used the PSM tendency score to match the implementation effect of empirical semicompulsory dividend sharing. It was found that the implementation of the policy led to more earnings management for refinancing listed companies in order to reach the regulatory threshold of the corresponding dividend sharing ratio. Yang Bao, Wanwei and Daisy Chow (2018) found that the semi-mandatory dividend policy led to the paradox of dividend-sharing while R\&D, which indicated that the semi-mandatory dividend policy had a regulatory paradox. Using panel data model, Li Jing and Jiang Debo (2017) found that the semi-mandatory dividend policy would increase the dividend willingness rather than the dividend level of listed companies, and the policy did not improve the dividend willingness and the dividend level of listed companies after refinancing.

Another view is that the semi-mandatory dividend policy not only increases the number of dividend-paying enterprises and the willingness to pay dividends, but also improves the corporate governance structure by reducing the agency costs of enterprises. Wei Zhihua, Li Maoliang and Li Changqing (2014) found that the semi-mandatory dividend policy not only improves the dividend payment level of listed companies, but also enhances the willingness of listed companies to pay cash dividends. Liu Xing, Tan Weirong and Li Ning (2016) found that the semi-compulsory dividend policy significantly increased the dividend payment level of listed companies with refinancing intention through the difference-in-difference-mode(DID). Xu Haoran and Liao Guanmin (2018) 
used the double difference model to find that the compulsory dividend policy reduced the free cash flow that controlling shareholders could abuse, greatly curbed the opportunistic behavior of large shareholders, and the payment of cash dividend also helped to reduce the second kind of agency cost of the company. An Qingsong (2012) empirical study found that the semi-mandatory dividend policy increased the dividend distribution of listed companies, and proved that the dividend distribution level of Chinese listed companies will reach the level of developed countries. Wei Zhihua, Li Changqing, Wu Yuhui and Huang Jiajia (2017) investigated that the semi-mandatory dividend policy significantly improved the willingness and level of cash dividend of listed companies with refinancing motivation by panel data.

In short, scholars have different idea about the effectiveness of the dividend policy issued by the SFC. Some argue that the dividend policy does not change the willingness of listed companies to pay dividends, so the effectiveness of the policy is questionable. Others believe that the dividend policy can improve the dividend willingness and dividend level of China's stock market. Comparing the two, the dividend policy is beneficial to remedy the legal vacancy in general, and will promote the improvement of the internal governance structure of listed companies, especially to suppress opportunistic behavior of management and reduce the loss of corporate value. Therefore, the mandatory dividend policy is a strategic choice with more advantages than disadvantages.

Throughout the existing literature, the mainstream view is that the CSRC dividend policy improves the dividend willingness and dividend level of listed companies, and achieves the effect of reducing agency costs by controlling the disposable cash flow of enterprises. Regard to the policy concerned, most scholars believe that this policy can improve the dividend payout level and willingness of listed companies. However, it should be pointed out that: firstly, the existing research focuses on the semi-compulsory dividend policy, and pays no necessary attention to the compulsory dividend policy, and pays less attention to the heterogeneity of the semi-compulsory dividend policy. Secondly, almost all the existing studies are based on empirical research. The empirical results show that the policy effect of mandatory dividend distribution is not timely modeled, which makes the mechanism of mandatory dividend distribution policy unclear and divergent opinions. In view of this, this paper not only establishes a mixed strategy complete information static game to explain the mechanism of mandatory dividend policy to restrain agency costs, but also makes 
quasi-natural experiments according to mandatory dividend policy, and uses DID model to test the inhibition of mandatory dividend policy on agency costs.

\section{Theoretical ANAlysis ANd ReSEARCH Hypothesis}

The separation of ownership and control of modern enterprises not only improves the production efficiency of the company, but also realizes the value-added of the enterprise. Since the high-ranking managers are no longer the residual security winners, the discharging and dereliction of duty of the executives are inevitable. However, the majority of shareholders who really have the residual demanding rights of enterprises have no motivation to closely supervise the executives because of the decentralization of equity. Therefore, the executives as rational people will pursue their own interests by abusing funds, on-the-job consumption, related transactions and over-investment. Maximization is not the maximization of shareholders' interests. In this way, serious agency problems will arise between owners and operators. In this regard, can mandatory dividend policy effectively reduce the agency cost of listed companies?

On the one hand, as a rational economic man, the motivation of manager opportunistic behavior is beyond doubt. They often use various moral hazard behaviors to increase private benefits. Therefore, only by adopting high-pressure measures such as mandatory dividend policy to overcome the opportunistic behavior of executives, can the agency cost of listed companies be significantly reduced. First of all, because the efforts of executives could not be effectively monitored, if the salary of executives would not compensate for the negative effects brought by the pursuit of maximizing shareholders' interests, then there will be inevitable opportunistic behavior of executives, either not working hard and shirking responsibility, or working hard to turn the surplus of enterprises into private benefits. Specifically, according to Feng Genfu and Zhao Juehang (2012), executives pursue private gains mainly through on-the-job consumption, affiliated transactions, over-investment for performance or projects with negative net present value. On-the-job consumption is a kind of expenditure paid by enterprises that does not increase the actual value of the company for managers to increase their own utility, such as buying luxury cars, entertainment consumption, luxury decoration of office space, etc. Obviously, the increase of on-the-job consumption will inevitably increase agency costs. Zhang Lili (2018) said that affiliated transaction is not only an important means for major shareholders to embezzle the interests of listed companies, but also that 
according to Shi Yong and Li Sihao (2018), its tunneling effect will significantly increase the risk of stock price crash. Over-investment means that the cash flow managers have in their hands is not the best investment project. Liu Yinguo (2008) found that when companies pay cash dividends, they will reduce the resources that executives can control. Then executives will choose between expanding the size of enterprises and cash dividends, and they will choose to continue to expand the size of enterprises. At this time, there is an over-investment phenomenon. Secondly, if we adopt mandatory dividend policy, we can re-establish an incentive and restraint mechanism between shareholders and executives, and force executives to work hard to maximize their personal utility, so as to achieve the goal of reducing agency costs. Yang Yi and Shen Yifeng (2004) found that cash dividends reduce the disposable cash of enterprises. If enterprises need to invest at this time, they will introduce third-party supervision, and the company's low agency costs will naturally be reduced. According to Yang Bao and Yuan Tianrong (2014), institutional investors can alleviate the first kind of agency costs between managers and shareholders in decentralized companies, and find that listed companies reduce the abuse of cash flow by managers through cash dividends, and also reduce agency costs. Hu Yaoting and Mahong (2017) found that the difference of agency cost would affect the relationship between cash dividend and corporate value. If the internal governance mechanism of the company is relatively perfect, the role of cash dividend in reducing agency cost will be greatly reduced. Active cash dividend issuance by listed companies is positively related to corporate value, but passive cash welfare issuance is not. Generally speaking, although executives have a strong motivation to pursue private benefits, the mandatory dividend policy can impose a hard constraint on this opportunism from outside the company, so the agency cost of the company will be reduced.

On the other hand, as an external shock, the mandatory dividend policy not only violates the internal, independent, free and decentralized decision-making will of all listed companies, but also would be superfluous. For those growing companies, it has become the burial products of the Iron Rooster company. Therefore, these policies will inevitably encounter various kinds of bright or dark in the process of implementation. Negative resistance leads to unsatisfactory policy results. Looking back on the contemporary financial history, it is not difficult to find that the semi-mandatory dividend policy in 2008 has a very limited impact on the "iron cock" companies without refinancing motives. Because the semi-mandatory dividend policy of that year linked the refinancing 
with dividend dividend, because most of the "iron cock" companies with longterm profits without dividend have no refinancing motive, so the semi-mandatory dividend policy does not have an impact on it. Liu Yinguo, Zhang Chen and Ruan Sumei (2014) found that the semi-mandatory dividend policy can restrain the agency costs by reducing free cash flow, and also found that the improvement of corporate governance level can increase the willingness and level of dividend sharing. Wei Zhihua, Li Changqing and Li Changqing (2014) empirically analyzed the impact of semi-mandatory dividend policy on Iron Cock Company, and found that the semi-mandatory dividend policy could not restrain the dividend payout of Iron Cock Company and did not reduce the proportion of Iron Cock Company. The dividend policy of Chen Yan, Li Xin and Li Mengshun (2015) has changed the current situation that listed companies do not pay dividends, but only has an impact on SEO enterprises. Statistics by Wang Zhiqiang and Zhang Weiting (2012) show that although the company's willingness to pay cash has increased, it does not rule out the suspicion that it only caters to the policy. Yu Yan and Wang Chunfei (2014) found that for listed companies with financing needs, semi-mandatory dividend would increase their dividend distribution. Wei Zhihua, Li Changqing, Wu Yuhui and Huang Jiajia (2017) verified that the semi-mandatory dividend policy could effectively reduce two types of agency costs. The change of dividend could be used as a good signal to indicate the company's performance, but it is not good for the company with SEO motivation. Knowing the past helps learning from the present. According to the historical experience and the existing economic logic, the policy of compulsory dividend will also face the embarrassment of semi-compulsory dividend sharing policy, that is, although the dividend policy can reduce the agency cost of enterprises, the negative resistance of listed companies will lead to a great discount of the effectiveness of the policy.

To sum up, under the high pressure of mandatory dividend policy, it is inevitable to increase the willingness to pay dividends of all listed companies, including "iron cock", so as to achieve the purpose of restraining agency costs. Because the CSRC mandatory dividend policy not only requires enterprises to make clear dividend plans and not to change at will, but also requires enterprises not to pay dividend to explain the use of funds, so the mandatory dividend policy can reduce the free cash flow of enterprises by requiring cash dividends, thus reducing various opportunistic behaviors of management and reducing enterprises. Agency cost. However, the negative resistance of management to 
external shocks should not be underestimated. Accordingly, the hypothesis of this study can be put forward:

Hypothesis 1: Mandatory dividend policy can significantly enhance the listed companies willingness to pay out dividend.

Hypothesis 2: Mandatory dividend policy can significantly reduce the listed companies agency cost

Hypothesis 3: Under the condition of asymmetry information, the effect of mandatory dividend policy will be unsatisfactory because of the resistance of listed companies.

\section{THEORITICAL MODEL}

The three research hypotheses can be proved by a mixed strategy complete information static game mentioned above in the theoretical model. Because of the unpredictability of paying, shareholder's increase is uncertain. The dividend distribution is not only affected by the net profit of the enterprise, but also by the supervision of shareholders. Driven by opportunism, it is uncertain whether executives will pay dividends or not. Thus, there is a typical mixed strategy game between executives and shareholders.

\section{Model Thought}

Although mandatory dividend policy can effectively reduce the agency cost of Listed Companies in general, it seriously deviates from the spirit of market contract in the decentralized decision-making of dividend policy, and will inevitably encounter negative resistance from capital market. Therefore, the effect of policy implementation will be greatly reduced and deviate from the expected goal of policy designers.

Firstly, the restraining effect of mandatory dividend policy on agency cost of listed companies is expected. On the one hand, the mandatory dividend policy can eliminate the uncertainty of cash dividend, ensure that shareholders can not only obtain a stable expected return, but also generate the impulse to increase their holdings, which will naturally lead to significant changes in the balance of supply and demand of the company's stocks, so that the stock supply exceeds demand and the stock price rises significantly. On the other hand, under the incentive of shareholder increase and stock price rise, executives will 
inevitably work hard to improve the expected return on investment projects and provide abundant cash flow for cash dividends.

Secondly, mandatory dividend policy not only challenges the independence and autonomy of decentralized decision-making of listed companies, but also impairs the private benefits of executives objectively. Therefore, it will inevitably be resisted negatively. For example, listed companies cater to the needs of regulatory departments by increasing annual dividend-sharing frequency, but also secretly reduce the cash dividend per share to protect private earnings. Eroded. That is to say, there are policies on the one hand and Countermeasures on the other.

\section{Model Assumptions}

Assumption 1: The cash dividends available to listed companies are positively correlated with managers' work effort e, so the current cash dividends can be expressed by $\alpha$ e. $\alpha$ is a coefficient not less than zero, which describes the willingness and level of dividend distribution; if it is zero, it means that the company has no willingness to pay dividends.

Assumption 2: All shareholders are homogeneous and hold one unit of company stock. They know nothing about the internal situation of the company's operating performance, and only decide whether to increase the company's stock according to the dividend or not. At the same time, in order to simplify the complexity of game equilibrium solution, it is assumed that the proportion of increase and decrease is $\pi$, and the capital gains obtained are all $\beta$, and there are $\pi>0$ and $\beta>0$.

Obviously, $\beta>0$ may not only be the reason for executive dividend, that is, for mature companies, rising stock prices usually mean that companies have the ability to generate after-tax profits to fund cash dividends, but also the basis for dividend-sharing, that is, for growth companies, even without dividends, stock prices will rise. At the same time, for shareholders, only when the capital gains are positive, can he have the motivation to reduce the company's shares without dividends or when the company's development prospects are not optimistic; otherwise, he should continue to hold in order to obtain a higher positive return on investment. This is very consistent with the phenomenon that many investors in the stock market have been held up for a long time.

Assumption 3: Suppose that the executive's income is a function of effort, and the executive's income consists of salary income and private income. 
The harder an executive works, the higher his wage earnings; while private earnings increase the effectiveness of an executive, they reduce shareholder dividend earnings. Therefore, the executive's earnings function can be expressed as follows:

$$
U_{g}=a e-b e^{2}+c
$$

The coefficients $a$ and $b$ are all positive. $a e-b e^{2}$ is the salary income of senior managers, e is the effort level of senior managers. The economic meaning of the salary income function is that shareholders pay Executives 'salaries according to their efforts, and Executives' salaries are concave functions of their efforts; $c$ is the private benefits of executives, because executives have no residual claim, so there will be indisputable opportunistic behavior of executives. If the executive compensation at this time is not enough to compensate for the negative effects of hard work when creating value for shareholders, they will choose on-the-job consumption and related transactions to indirectly compensate for their negative effects.

Assumption 4: According to the dividend model, it is assumed that shareholders' earnings consist of cash dividends and capital gains, and that dividend gains should be mainly a function of managers' efforts.

In other words, the efforts of executives will create more corporate surplus, increase cash dividends that can be allocated to shareholders, and also release a signal that the business is doing well. Thus, the return function of holding a unit of stock can be expressed as follows

In other words, the efforts of executives will create more corporate surplus, increase cash dividends that can be allocated to shareholders, and also release a signal that the business is doing well. Thus, the return function of holding one unit of stock can be expressed as follows:

$$
\mathrm{U}_{\mathrm{d}}=\alpha \mathrm{e}\left(\text { or } \frac{\alpha \mathrm{e}}{\mathrm{r}-\mathrm{g}}\right)+\beta
$$

Among them, the coefficients $\alpha$ and $\beta$ are positive; $\alpha e$ is the cash dividend of the current period, $\frac{\alpha \mathrm{e}}{\mathrm{r}-\mathrm{g}}$ is the sum of the discounted value of dividends obtained by shareholders when they choose to hold them for a long time, $\beta$ is the present value of capital gains obtained by one-time transactions, $\mathrm{R}$ is the present value of capital gains obtained by one-time transactions, $r$ is the discount- 
ed value, and $g$ is the growth rate of dividends, in which cash dividends are the function of managers' efforts, while the present value of capital gains obtained by one-time transactions is constant.

\section{Strategy and Payment Matrix of Game Parties}

As mentioned above, according to the strategies of both players, the profit functions of both players can be expressed as follows:

Table 1. Payoff Matrix

\begin{tabular}{|c|c|c|}
\hline & $\begin{array}{l}\text { Decrease } \\
(1-q)\end{array}$ & $\begin{array}{l}\text { Increase } \\
(q)\end{array}$ \\
\hline $\begin{array}{c}\text { Not to pay } \\
(1-p)\end{array}$ & $0,(1-\pi) \frac{\alpha e(1+\mathrm{r})}{r}+\pi \beta$ & $\frac{\mathrm{ae}^{-\mathrm{be}^{2}+\mathrm{c}}}{r},(1+\pi) \alpha e \frac{(1+r)}{(r-g)}$ \\
\hline $\begin{array}{c}\text { Pay } \\
(p)\end{array}$ & $\mathrm{ae}-\mathrm{be}^{2}-\mathrm{c}, \pi \beta+\pi \alpha e+\frac{(1-\pi) \alpha e}{r}$ & $\frac{\mathrm{ae}^{-\mathrm{be}^{2}}}{r-g}, \alpha e+\frac{(1+\pi) \alpha e}{(r-g)}$ \\
\hline
\end{tabular}

So u r c e : author's mathematical deduction.

Among them, means to increase the holding of listed companies'stock units, and the other variables are consistent with the above. The economic implications of this matrix are as follows:

(1) The upper left chooses the profit function of both sides when executives choose no dividend and shareholders choose to reduce their holdings. Firstly, for executives, if shareholders choose to reduce their holdings because the company does not pay dividends, the reduction will cause the company's stock price to decline, then executives will face the fate of impeachment and dismissal, so the current income of executives is 0 , that is, unemployment will offset his wage income. Secondly, for shareholders, if they disagree with the company's non-dividend policy or are not optimistic about the company's development prospects, they can take a foot-to-foot vote to reduce their holdings of the company's shares. At this time, the earnings consist of two parts: the shareholders get the capital gains $\pi \beta$ of the current reduction and the discount $(1-\pi) \alpha e \frac{(1+r)-\frac{1}{(1+r)^{n}}}{r}$ of accumulated undistributed dividends obtained by continuing to hold $(1-\pi)$ Unit stock. When $\mathrm{n} \rightarrow \infty$, the limit of 
$(1-\pi) \alpha e \frac{(1+r)-\frac{1}{(1+r)^{n}}}{r}$ is $(1-\pi) \frac{\alpha e(1+r)}{r}$, so the total earnings of the shareholder is $(1-\pi) \frac{\alpha e(1+r)}{r}+\pi \beta$.

(2) The upper right chooses the profit function of the two sides when the executive chooses not to dividend and the shareholder chooses to increase the ownership. Firstly, for executives, if executives choose not to pay dividends and shareholders choose to continue holding, this shows that the company's nondividend behavior has been recognized by shareholders. So they will get the salary of ae $-b^{2}$ and private interest $c$, i.e., his discounted income from future periods should be $\frac{a e-b e^{2}+c}{r}$. Secondly, for shareholders, since they agree with the dividend-free strategy of senior managers, they have reason to believe that long-term holding of company stocks may lead to accumulated undistributed dividends in a future period, i.e. a huge capital gain. Therefore, they will choose to increase their holding of unit stocks with the discount value of their total earnings. The discount value of its total income is $(1+\pi) \alpha e \frac{1-\left(\frac{1+g}{1+r}\right)^{n}}{1-\left(\frac{1+g}{1+r}\right)^{n}}$. When $\mathrm{n} \rightarrow \infty$, it is $(1+\pi) \alpha e \frac{(1+r)}{(r-g)}$ for limit of the discount value of $(1+\pi)$ the longterm shareholder's shares.

(3) The bottom left is the earnings function of both sides when executives choose dividends and shareholders choose to reduce their holdings. Executives choose to pay dividends, but suffer from shareholders' reduction. This makes executives bear double losses psychologically, that is, not only do they not gain potential private benefits, but also lose disposable free cash flow, so their earnings are $a e-b e^{2}-c$. It should be pointed out in particular that because of the influence of tenure system and managers' market competition, senior managers are not discounted here. For shareholders, reduction can not only obtain current capital gains, but also obtain discount income from the sum of dividends $(1-\pi)$ and continue to hold them, $\pi \beta+\pi \alpha e+\frac{(1-\pi) \alpha e}{r}$.

(4) The bottom right is the profit function of both sides when executives choose dividends and shareholders choose to increase their holdings. First, for 
senior managers, choosing to dividend and let the dividend grow at a fixed rate $\mathrm{G}$ will enable them to reach tacit understanding with shareholders and agree with each other. At this time, although the choice of dividends abandons the possibility of obtaining private benefits, the positive signals released by dividends make the status of executives not threatened, and can continue to obtain the discounted value $\frac{\text { ae-be }}{\mathrm{r}-\mathrm{g}}$ of salary income that the future operating compa-

ny can bring for a continuous term of office, the reason why $r-g$ is chosen as the discount rate of executive's salary income is that the executive can completely convert his salary income into stock in order to obtain the potential income of the company's growth. As far as shareholders are concerned, the rational choice at this time is to increase the holding of company stocks, not only to obtain the dividend income of the current period, but also to obtain all the intrinsic value of stocks when they hold stocks for a long time, so the total income of shareholders at this time is: $\alpha e+\frac{(1+\pi) \alpha e}{(r-g)}$.

\section{Equilibrium ANALYSIS OF GAME}

\section{(1) Equilibrium of Executives}

Given the shareholder's holding probability q, the expected earnings of executives when they choose to dividend and non-dividend are respectively.

$$
\begin{aligned}
& E(\text { pay })=(1-q)\left(a e-b e^{2}-c\right)+q\left(\frac{a e-b e^{2}}{r-g}\right) \\
& E(\text { not pay })=(1-q)(0)+q\left(\frac{a e-b e^{2}+c}{r}\right)
\end{aligned}
$$

Therefore, let E (pay dividend ) = E ( pass dividend), after a series of algebraic operations,

$$
q=\frac{r(r-g)(a-b \alpha e-1)}{r-g(a-b \alpha e+1)+r(r-g)(a-b \alpha e-1)}
$$

According to the principle of equal expectation payment, there should be no difference between the expected returns of dividend-sharing and non-divi- 
dend-sharing for executives at the Nash equilibrium of mixed strategy in game theory. Equation (5) shows that whether shareholders hold shares of listed companies depends mainly on discount rate $r$, dividend growth rate $g$ and dividend per share $d$.

\section{(2) Equilibrium of Shareholders}

According to the matrix, given the dividend probability $q$ of executives, the expected returns of shareholders when they choose to hold or not are respectively:

$$
\begin{aligned}
& E(\text { Increase })=(1-p)\left((1+\pi) \alpha e \frac{(1+r)}{(r-g)}\right)+p\left(\alpha e+\frac{(1+\pi) \alpha e}{(r-g)}\right) \\
& E(\text { Decrease })=(1-p)\left((1-\pi) \frac{\alpha e(1+r)}{r}+\pi \beta\right)+p\left(\pi \beta+\pi \alpha e+\frac{(1-\pi) \alpha e}{r}\right)
\end{aligned}
$$

Based on the principle of equal expectation payment, there should be no difference between the expected returns of shareholders who choose to hold and not hold on the Nash equilibrium of mixed strategy. Therefore, let E(hold)=E(not hold), it is

$$
p=1-\frac{\pi+\frac{\pi \beta}{d}+\frac{(1-\pi)}{r}-\frac{(1+\pi)}{(r-g)}-1}{2(\pi-1)+\frac{(1+\pi) r}{(r+g)}}
$$

\section{(3) Nash Equilibrium and Mandatory Dividend Policy}

According to equation (3) and (5), the mixed strategy Nash equilibrium (p, q) of the complete information static game is obtained.

$$
\left(1-\frac{\pi+\frac{\pi \beta}{d}+\frac{(1-\pi)}{r}-\frac{(1+\pi)}{(r-g)}-1}{2(\pi-1)+\frac{(1+\pi) r}{(r+g)}}, \frac{r(r-g)(a-b \alpha e-1)}{r-g(a-b \alpha e+1)+r(r-g)(a-b \alpha e-1)}\right)
$$

At this time, for shareholders, if the compulsory dividend system is implemented, the dividend probability $\mathrm{p}=1$ is always valid on Nash equilibrium, and this result can be brought into equilibrium conditions. 


$$
e=\frac{\pi \beta}{\alpha\left(1+\frac{1+\pi}{r-g}-\frac{1-\pi}{r}-\pi\right)}
$$

This means that, under the influence of mandatory dividend policy, the degree of Executives' work effort $e$ depends on the discount rate $r$, the current capital gain $\beta$ of the company's stock and the shareholder's increase ratio $\pi$, the dividend growth rate $g$, the dividend distribution ratio $\alpha$, etc.

(i) Under the assumption of continuous derivability, the first-order partial derivative of executive effort $e$ to dividend ratio $\alpha$ can be obtained.

$$
\frac{\partial e}{\partial r}=\frac{\pi \beta}{\alpha} \frac{1}{\left(1+\frac{1+\pi}{r-g}-\frac{1-\pi}{r}-\pi\right)^{2}}\left(\frac{1+\pi}{(r-g)^{2}}-\frac{1-\pi}{r^{2}}\right)>0
$$

According to the assumption of the model, the upper formula is always positive. This means that at the Nash equilibrium of mixed strategy, the higher the discount rate, i.e. the reward rate necessary for a company's investment project, the higher the level of hard work of executives. At this time, the high rate of return on investment projects can ensure that the company produces enough cash flow to pay dividends, so executives are not afraid of the policy assessment of regulatory authorities, nor the benchmarking effect of peers and competitive pressures, thus feeling a bright future and full of energy.

(ii) Under the assumption of continuous derivability, the first-order partial derivative of managerial effort $e$ to current capital gain $\beta$ can be obtained:

$$
\frac{\partial e}{\partial \beta}=\frac{\pi}{\alpha} \frac{1}{1+\frac{1+\pi}{r-g}-\frac{1-\pi}{r}-\pi}>0
$$

This shows that the market performance of corporate stock is positively correlated with the managers 'hard work, that is, the higher the stock price, the more incentive the managers to work hard, because not only their work can be affirmed by the market, but also the stock price rise can attract more investors to hold corporate stock. At the same time, since the stock price is based on the company's performance, which means that the company can provide enough cash flow for cash dividend, so executives need not worry about their own dividend pressure, so they can be light-loaded, without worries, and work hard with all their heart and soul. 
(iii) Under the assumption of continuous differentiability, the partial derivative of managerial effort degree $e$ to shareholder increase ratio $\pi$ can be obtained.

$$
\frac{\partial e}{\partial \pi}=: \frac{\beta\left(1+\frac{1}{r-g}-\frac{1}{r}\right)}{\left(1+\frac{1+\pi}{r-g}-\frac{1-\pi}{r}-\pi\right)^{2}}>0
$$

According to the previous assumption, given the dividend discount rate $r$ and dividend growth rate $g, \frac{\partial \mathrm{d}}{\partial \pi}>0$, is always valid. As long as the shareholders' meeting becomes a loyal supporter of the senior managers, keeps increasing the stock holdings of the company, and continuously makes a positive evaluation of the company's performance, the senior managers will work hard without hesitation, so that the company can achieve profitability and continuously improve the dividend level, thereby improving the earnings of the shareholders and senior managers. This is a win-win and mutually beneficial strategic interaction.

(iv) Under the assumption of continuous derivability, the first-order partial derivative of executive effort $e$ to dividend growth rate $g$ is obtained.

$$
\frac{\partial e}{\partial g}=-\frac{\pi \beta}{\alpha} \frac{1}{\left(1+\frac{1+\pi}{r-g}-\frac{1-\pi}{r}-\pi\right)^{2}} \frac{1+\pi}{(r-g)^{2}}<0
$$

Under the assumption of continuous derivability, the first-order partial derivative of executive effort e to dividend growth rate $g$ can be obtained, which shows that the growth of dividend growth rate $g$ will inhibit the enthusiasm and effort of executives. This is because the mandatory dividend policy has formed a stable expectation of cash dividends. If the dividends continue to grow, the dividends in the distant future will become more and more, which will make executives overwhelmed unless the company's dividends can be distributed continue to grow at the rate of $r$. Obviously, this is a very strict and unrealistic assumption that there can be no fluctuation in company performance. In this way, dividend growth rate $g$ may not be enough to worry about in the short term, but it will be the last straw to crush the camels in the long run, which will cause a heavy blow to the enthusiasm of executives.

(v) Under the assumption of continuous derivability, the first-order partial derivative of executive effort $e$ to dividend ratio $\alpha$ is obtained. 


$$
\frac{\partial e}{\partial \alpha}=-\frac{\pi \beta}{\alpha^{2}\left(1+\frac{1+\pi}{r-g}-\frac{1-\pi}{r}-\pi\right)}<0
$$

According to equation (14), it can be found that the degree of efforts of executives is inversely proportional to their dividend-sharing ratio. The economic logic behind it: With the increase of the dividend proportion, the company's disposable free cash flow will decrease accordingly, which will not only hinder executives from increasing their private benefits, but also make the dividend distribution system produce an unbalanced mentality, that is, shareholders gain nothing without any reason, using the identity of the capital owner to embezzle their own labor results. Therefore, it is self-evident that the executive's work effort e decreases with the increase of the dividend ratio $\alpha$.

\section{Model Conclusion}

First of all, needless to say, since it is a mandatory dividend policy, whether or not out of sincerity, listed companies will show a significantly higher willingness to pay dividends than before.

Secondly, according to equation (10)-(12), the implementation of mandatory dividend policy will significantly encourage executives to work hard and reduce the agency cost of corporate governance. On the one hand, the mandatory dividend policy will undoubtedly increase the expected returns of investors, which will naturally stimulate investors to increase their ownership of company stocks, which will change the balance between supply and demand of company stocks, further boost the rise of company stock prices, so that executives will be motivated by both shareholder ownership and stock price rise, and work harder. On the other hand, since executives are willing to work harder, the expected return on investment projects will naturally rise. In this way, executives can provide a steady stream of cash flow for cash dividends. It is selfevident that the exogenous impact of mandatory dividend policy can construct a virtuous circle between executives and shareholders: mandatory dividend policy - cash dividend of the company - shareholders and investors holding more shares of the company - stock price rise - executives working hard - the next round of cash. Unexpectedly, this cycle will start again and again.

Finally, according to equation (13) and (14), some factors of corporate dividend policy itself will lead to the actual effect of mandatory dividend policy deviating from the expected goal of the policy. Specifically, whether it is cash 
dividend ratio or dividend growth rate, it will create pressure and threat to the performance of executives in the long run. Therefore, as a rational economic man, executives may take a negative resistance strategy at the beginning to create a buffer space for their future strategic adjustment, such as deliberately lowering the cash dividend ratio and setting a close approach. Dividend growth rate at 0 , etc. However, in this way, the effect of mandatory dividend policy will be weakened invisibly.

\section{RESEARCH DESIGN}

\section{Selection of Empirical Model}

\section{(1) Difference-Difference Model (DID)}

The difference-difference model can be used to test the effectiveness of policy. Using exogenous policy shocks to do quasi-natural experiments, the double difference can overcome the influence of other factors on the results, so the net impact of policy shocks can be obtained. Because of the exogenous nature of policy shocks and the diversity of policy objects, there will be treatment groups affected by policies and control groups not affected by policies. The DID model is to test the effect of the policy by comparing the changes of the experimental group and the control group before and after controlling other factors.

In order to test the impact of mandatory dividend policy on agency cost, this paper makes a quasi-natural experiment on the implementation of mandatory dividend policy, uses DID method to identify causality. According to the external impact of "mandatory dividend policy", we compare the policy effects before and after the external impact, and then analyze whether the mandatory dividend policy will reduce the agency cost of listed companies. On November 9, 2011, Guo Shuqing, chairman of the CSCR, proposed that listed companies should pay dividends. On November 9, 2011, the "mandatory dividend" incident affected the whole stock market: after 2012, the dividend rate of the stock market further increased, after 2015, the dividend of listed companies increased substantially, and by 2017 , about $80 \%$ of listed companies had dividends. Therefore, the dividend distribution of many companies is affected by the sudden impact of this policy, which provides us with good quasi-natural experimental conditions. According to the DID model, this paper constructs a model (1) based on DID: 


$$
\begin{aligned}
& \text { agent }_{i t}=\alpha+\beta_{1} \text { treat }_{i t}+\beta_{2} \text { law }_{i t}+\beta_{3} \text { law }_{i t} * \text { treat }_{i t}+\beta_{4} \text { roe }_{i t}+\beta_{5} \text { bps }_{i t}+\beta_{6} \text { lev }_{i t}+ \\
& \beta_{7} \text { capex }_{i t}+\beta_{8} \text { Sh }_{i t}+\beta_{9} \text { Sretained }_{i t}+\beta_{10} \text { dual }_{i t}+\beta_{11} \text { firmage }_{i t}++\beta_{12} \text { cash }_{i t}+ \\
& \beta_{13} \text { SOE }_{i t}+\beta_{14} \text { GEM }_{i t}+\beta_{15} \text { year }_{i t}+\beta_{15} \text { industrey }_{i t}+\varepsilon_{i t}
\end{aligned}
$$

Among them, agent ${ }_{i t}$ is agency cost of company $i$ at time $t$; treat stands for dummy variables in experimental group (The Iron Cock Company, which did not pay dividends for three consecutive years before the policy was introduced, was the first to be affected by the policy of "mandatory dividend policy". The treat is 1 , which indicates that listed companies are affected by policy shocks; otherwise, 0 ; law is a policy time variable, with 0 before policy and 1 after policy; and coefficient of $\beta_{3}$ describes the impact of mandatory dividend policy on agency costs, which is the focus of this research.

Table 2. DID Subgroup

\begin{tabular}{|l|c|c|c|}
\hline \hline & Before Policy & After Policy & Total \\
\hline \hline Controlling Group & 6141 & 10312 & 16453 \\
\hline Experimental Group & 1345 & 5001 & 6346 \\
\hline Total & 7486 & 15313 & \\
\hline
\end{tabular}

S o u r c e : author's calculation based upon the Great Intelligence Database in China.

\section{(2) Test of Parallel Trend Hypothesis}

However, one of the prerequisites is that the parallel trend hypothesis is satisfied between the experimental group and the control group for unbiased estimation results of double difference method, that is, the treatment group and the control group should have the same change trend before the event occurs, otherwise the double difference method will overestimate or underestimate the effect of the event. In order to verify the hypothesis of parallel trend, this paper investigates it with the aid of event study method. If the hypothesis of parallel trend holds, then the reduction of agency cost of Iron Cock Company will only occur after the mandatory dividend policy, and there should be no significant difference between the change trend of the experimental group and the controlling group before that. The test of parallel trend hypothesis can also eliminate the problem of self-selection in DID regression to some extent. 
Table 3. Equilibrium trend hypothesis test

\begin{tabular}{|l|c|c|c|c|c|c|}
\hline \hline \multicolumn{1}{|c|}{ Variable } & $\mathbf{2 0 1 0}$ & $\mathbf{2 0 1 1}$ & $\mathbf{2 0 1 2}$ & $\mathbf{2 0 1 3}$ & $\mathbf{2 0 1 4}$ & $\mathbf{2 0 1 5 - 2 0 1 7}$ \\
\hline \hline Agent I & $\begin{array}{c}-0.006 \\
(-1.24)\end{array}$ & $\begin{array}{c}-0.006 \\
(-1.16)\end{array}$ & $\begin{array}{c}-0.016^{* * *} \\
(-3.37)\end{array}$ & $\begin{array}{c}-0.012^{* * *} \\
(-2.57)\end{array}$ & $\begin{array}{c}-0.011^{* *} \\
(-2.26)\end{array}$ & $\begin{array}{c}-0.016^{* * *} \\
(-4.24)\end{array}$ \\
\hline $\begin{array}{l}\text { Controlling } \\
\text { Variable }\end{array}$ & control & control & control & control & control & control \\
\hline Year & control & control & control & control & control & control \\
\hline Industry & control & control & control & control & control & control \\
\hline $\mathrm{N}$ & 23129 & 23129 & 23129 & 23129 & 23129 & 23129 \\
\hline \hline
\end{tabular}

Note: Standard errors in parentheses. ${ }^{* * *} \mathrm{p}<0.01,{ }^{* *} \mathrm{p}<0.05,{ }^{*} \mathrm{p}<0.1$

S o u r c e : author's calculation based upon the Great Intelligence Database in China.

According to table 3, we can see that the coefficients of Before 2 and Before 1 before the policy are not significant, that is to say, there is no significant difference in agency costs before the policy. However, in the current year, the year after the policy and the remaining three years after the policy, the coefficient of After2 is 1\%. Only in the two years after the policy, the level of After 2 is $5 \%$. That is, after the policy, the proxy cost decreases significantly. Therefore, the parallel trend assumption required by the double difference model is satisfied.

\section{Definition and Description of Variables}

\section{(1) Explained Variables}

Agent cost. Referring to Wei Zhihua, Wu Yuhui and Li Changqing (2012), the agency cost rate (agent, management cost/operating income) was used to measure the agency cost between shareholders and managers. That is to say, the higher the management fee rate is, the higher the agency cost of listed companies is.

\section{(2) Explanation Variables and Control Variables}

The mandatory dividend policy (law) was proposed on November 9, 2011, so the mandatory dividend policy (after 2012, the value is 1, otherwise 0). For the control variables, using the existing literature for reference, this paper regards 
asset-liability ratio (lev), profitability (roe), large shareholder shareholding ratio (sh1), enterprise asset investment (capex), year and industry dummy variables as control variables. Specific definitions and calculations of each variable are shown in table 3.

Table 4. Variable Definition Measure

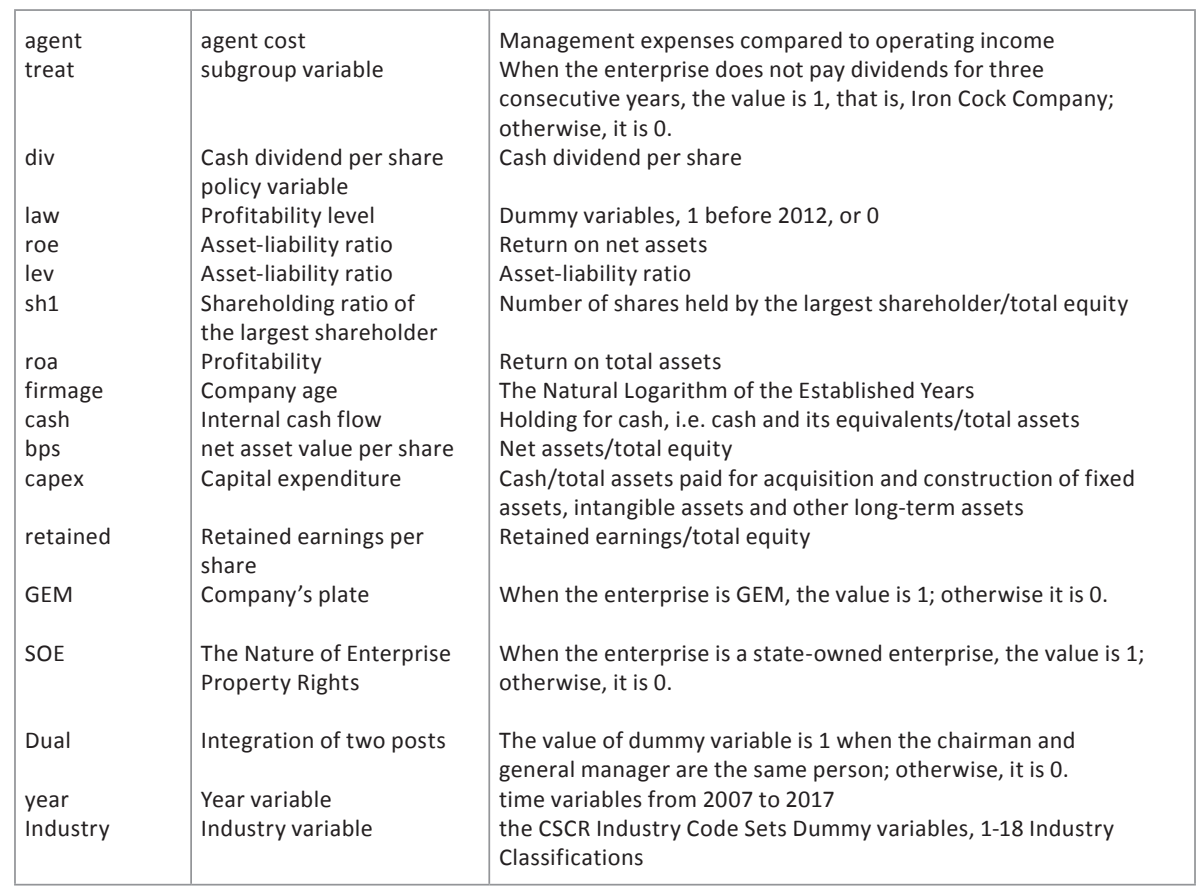

S o u r c e : author's collection based upon the Great Intelligence Database in China.

\section{Descriptive Statistics of Main Variables}

Table 5 is a descriptive statistical analysis of the main variables. During the 11 years, the average dividend distribution of listed companies was only 0.08 . This shows that the dividend distribution of listed companies is not enough. The maximum cash dividend per share is 11 , which indicates that some companies with high dividends have raised the overall average dividend distribution level. The maximum value of cash to total assets ratio is 0.96 , while the minimum value is -0.16 , but the average value is 0.18 , which indicates that there are two extremes of cash. For cash-rich enterprises, it is easy to generate agen- 
cy costs; but for cash-negative enterprises, it means that the operating performance of enterprises is not good. If such companies pay out cash, large shareholders will empty the listed companies. This may result in agency costs. The average value of agency cost is $8 \%$, and its maximum value is 0.99 , which means that the management cost accounts for the whole business income. This shows that the agency cost of listed companies is higher. The average share-holding ratio of the first largest shareholder is $36 \%$, which indicates that the listed companies in China are not decentralized shareholders.

Table 5. Descriptive Statistics of Main Variables

\begin{tabular}{|c|c|c|c|c|c|c|}
\hline variable & $\mathbf{N}$ & mean & sd & p50 & $\min$ & $\max$ \\
\hline $\begin{array}{l}\text { agent } \\
\text { div }\end{array}$ & $\begin{array}{l}36135 \\
36135\end{array}$ & $\begin{array}{l}0.08 \\
0.08\end{array}$ & $\begin{array}{l}0.08 \\
0.18\end{array}$ & $\begin{array}{l}0.07 \\
0\end{array}$ & $\begin{array}{l}0 \\
0\end{array}$ & $\begin{array}{l}0.99 \\
11\end{array}$ \\
\hline roa & 30595 & 0.10 & 0.09 & 0.08 & -0.77 & 1.79 \\
\hline roe & 30468 & 0.14 & 0.24 & 0.11 & -28.29 & 11.81 \\
\hline lev & 30550 & 0.44 & 0.20 & 0.44 & 0 & 1 \\
\hline sh1 & 23815 & 0.36 & 0.15 & 0.34 & 0 & 1 \\
\hline bps & 30483 & 4.33 & 4.14 & 3.60 & -0.09 & 302.7 \\
\hline capex & 30326 & 0.06 & 0.06 & 0.05 & 0 & 0.68 \\
\hline Sretained & 30571 & 1.69 & 3.35 & 1.24 & -17.78 & 301.7 \\
\hline dual & 36135 & 0.30 & 0.46 & 0 & 0 & 1 \\
\hline cash & 30330 & 0.18 & 0.15 & 0.14 & -0.16 & 0.96 \\
\hline firmage & 36135 & 2.93 & 0.30 & 2.94 & 1.10 & 4.09 \\
\hline SOE & 36135 & 0.30 & 0.46 & 0 & 0 & 1 \\
\hline GEM & 36135 & 0.22 & 0.41 & 0 & 0 & 1 \\
\hline industry & 36135 & 12.78 & 4.28 & 15 & 1 & 18 \\
\hline
\end{tabular}

S o u r c e : author's calculation based upon the Great Intelligence Database in China.

\section{Data Sources}

This paper chooses A-share companies in Shanghai and Shenzhen Stock Exchanges from 2007 to 2017 as research samples, and carries out the following processing: excluding financial enterprises, ST companies, missing data (agency cost missing data and new listed companies in 2018), excluding listed 
companies with negative ownership rights and interests. A total of 36153 valid samples were obtained. The database used in this paper is from the Great Intelligence Database. The data processing in this paper is completed by stata13.0. At the research time point, due to the mandatory dividend policy proposed on November 9, 2011, in order to examine the impact of the policy shocks, this paper chooses 2012 as the policy deadline, before 2012 as the variable before the policy, after 2012 as the variable analysis after the policy, so as to more accurately examine the impact of the policy.

\section{EMPIRICAL RESUlts AND ANALYSIS}

This part mainly examines whether mandatory dividend policy has restrained the agency cost before and after the implementation of the policy, and through the analysis of intermediary utility, further studies and analysis find that the mandatory dividend distribution policy can reduce the agency cost of enterprises.

\section{Preliminary Testing of Dividend Willingness and Dividend Level of Listed Companies}

Table 6 The dividend distribution of A-share enterprises in Shanghai and Shenzhen Stock Exchanges from 2007 to 2017 shows that the number of dividendsharing enterprises as a whole is increasing year by year. But before 2015, the number of dividend-sharing enterprises is relatively small, and after 2016, the proportion of dividend-sharing has increased to $70 \%, 80 \%$, indicating that the mandatory dividend policy has a very significant effect only after 2015. From the proportion of dividends, although the level of dividends increased, dividends only accounted for about $30 \%$ of net profit, of which the dividend payment rate in the 2012 policy period was $41 \%$ higher. At this time, because the policy had just been introduced, listed companies had the suspicion of catering to the regulatory authorities. In a word, the willingness to pay dividends of Chinese listed companies is rising, but the dividend level is not very high. Therefore, hypothesis 1 is proved. 
Table 6. Dividend distribution of A-share enterprises in Shanghai and Shenzhen from 2007 to 2017

\begin{tabular}{|l|c|c|c|c|c|c|c|c|c|c|c|}
\hline \hline \multicolumn{1}{|c|}{ Accounting Year } & $\mathbf{2 0 0 7}$ & $\mathbf{2 0 0 8}$ & $\mathbf{2 0 0 9}$ & $\mathbf{2 0 1 0}$ & $\mathbf{2 0 1 1}$ & $\mathbf{2 0 1 2}$ & $\mathbf{2 0 1 3}$ & $\mathbf{2 0 1 4}$ & $\mathbf{2 0 1 5}$ & $\mathbf{2 0 1 6}$ & $\mathbf{2 0 1 7}$ \\
\hline \hline $\begin{array}{l}\text { Number of dividend- } \\
\text { sharing Enterprises }\end{array}$ & 735 & 772 & 932 & 1230 & 1521 & 1686 & 1772 & 1852 & 1899 & 2326 & 2675 \\
\hline $\begin{array}{l}\text { The proportion } \\
\text { of dividend-sharing } \\
\text { Enterprises }\end{array}$ & 21 & 23 & 28 & 37 & 45 & 50 & 53 & 55 & 56 & 69 & 80 \\
\hline $\begin{array}{l}\text { Mean cash dividend } \\
\text { per share }\end{array}$ & 0.16 & 0.15 & 0.16 & 0.2 & 0.18 & 0.16 & 0.14 & 0.15 & 0.14 & 0.16 & 0.18 \\
\hline $\begin{array}{l}\text { Mean cash dividend/ } \\
\text { net profit }\end{array}$ & 0.37 & 0.43 & 0.36 & 0.35 & 0.35 & 0.41 & 0.39 & 0.36 & 0.37 & 0.35 & 0.36 \\
\hline \hline
\end{tabular}

S o u r c e : author's calculation based upon the Great Intelligence Database in China.

\section{The Effect of mandatory dividend policy to agency cost}

In order to test the inhibitory effect of mandatory dividend policy on agency cost of the experimental group and the control group, according to DID model (1), the effect of policy implementation on agency cost of the company was observed to test hypothesis 2 . The estimated results of the double difference model of agency cost difference between the experimental group and the control group are shown in table 7.

Table 7 reports the regression results of the mandatory dividend policy to suppress agency costs of Iron Cock Company. Column (1) is a simple doubledifference model with law*treatment coefficient of -0.0043 and significant at $1 \%$ level, which shows that the mandatory dividend policy significantly reduces the agency cost of Iron Cock Company. On this basis, we continue to introduce other control variables at the corporate level, namely, asset-liability ratio (lev), net assets per share (bps), the largest shareholder shareholding ratio (sh1), capital expenditure (capex) and retained earnings per share (Sretained). The regression results show that the significance of law * treatment has not changed, but the coefficient has further doubled. On the basis of column (2), we further introduce the situation of two-position integration (dual), firm age, cash flow, property right nature (SEO) and GEM, and find that the coefficient of law * treatment is -0.0117 and significant at $1 \%$ level. Among them, the combination of two positions, the company's internal cash and the company's establishment years will significantly increase the agency cost of the enterprise, 
that is, the concurrent appointment of the general manager and the chairman of the board of directors indicates that the general manager has greater rights, and opportunistic behavior will occur at this time; the company's internal cash flow will also increase the agency cost of the company, after all, sufficient cash can ensure that opportunistic behavior has a definite purpose. If the company is established for a long time, its internal interests will be solidified easily, which will further increase the agency cost. In conclusion, the introduction of the mandatory dividend policy in 2012 has indeed reduced the agency cost of Iron Cock.

Table 7. Regression result about mandatory dividend policy reducing agency cost

\begin{tabular}{|c|c|c|c|}
\hline & equation (1) & equation (2) & equation (3) \\
\hline VARIABLES & agent & agent & agent \\
\hline \multirow[t]{2}{*}{ Law*treat } & $-0.0043^{* *}$ & $-0.0092 * * *$ & $-0.0117^{* * *}$ \\
\hline & $(-2.4287)$ & $(-3.9710)$ & $(-5.0862)$ \\
\hline \multirow[t]{2}{*}{ treat } & $0.0141 * * *$ & $0.0167 * * *$ & $0.0175^{* * *}$ \\
\hline & (9.6071) & $(8.3261)$ & (8.7498) \\
\hline \multirow[t]{2}{*}{ law } & $0.0188^{* * *}$ & $0.0157^{* * *}$ & $0.0142^{* * *}$ \\
\hline & (9.2095) & (6.6637) & (5.9801) \\
\hline \multirow[t]{2}{*}{ roe } & $-0.0200 * * *$ & $-0.0276 * * *$ & $-0.0287 * * *$ \\
\hline & $(-12.4464)$ & $(-14.6638)$ & $(-15.3697)$ \\
\hline \multirow[t]{2}{*}{ lev } & & $-0.1055^{* * *}$ & $-0.0902 * * *$ \\
\hline & & $(-44.7019)$ & $(-33.9950)$ \\
\hline \multirow[t]{2}{*}{ sh1 } & & $-0.0475^{* * *}$ & $-0.0448 * * *$ \\
\hline & & $(-16.4005)$ & $(-15.1244)$ \\
\hline \multirow[t]{2}{*}{ bps } & & $-0.0016 * * *$ & $-0.0023 * * *$ \\
\hline & & $(-6.8233)$ & $(-9.6156)$ \\
\hline \multirow[t]{2}{*}{ capex } & & -0.0082 & -0.0061 \\
\hline & & $(-0.9536)$ & $(-0.7018)$ \\
\hline \multirow[t]{2}{*}{ sretained } & & $-0.0022 * * *$ & $-0.0012 * * *$ \\
\hline & & $(-5.7340)$ & $(-3.1142)$ \\
\hline dual & & & $0.0091^{* * *}$ \\
\hline
\end{tabular}


Table 7. Regression result...

\begin{tabular}{|l|c|c|c|}
\hline \hline \multicolumn{1}{|c|}{ VARIABLES } & equation (1) & equation (2) & equation (3) \\
\hline \hline & agent & agent & agent \\
\hline cash & & & $(8.5294)$ \\
\hline & & & $0.0216^{* * *}$ \\
\hline firmage & & & $(5.9857)$ \\
\hline & & & $0.0035^{*}$ \\
\hline SOE & & & $(1.8419)$ \\
\hline & & & $0.0020^{*}$ \\
\hline GEM & & & $(1.9084)$ \\
\hline & & & $0.0211^{* * *}$ \\
\hline Constant & & & $(15.5302)$ \\
\hline & $0.0806^{* * *}$ & $0.1660^{* * *}$ & $0.1442^{* * *}$ \\
\hline Year & $(26.7714)$ & $(43.1766)$ & $(20.2600)$ \\
\hline Industry & Control & Control & $\begin{array}{l}\text { Control } \\
\text { Control }\end{array}$ \\
\hline Observations & Control & 22,800 & 22,799 \\
\hline R-squared & 30,468 & 0.2600 & 0.2728 \\
\hline F & 0.1743 & 228.6 & 213.4 \\
\hline
\end{tabular}

Note: Standard errors in parentheses. ${ }^{* * *} \mathrm{p}<0.01,{ }^{* *} \mathrm{p}<0.05,{ }^{*} \mathrm{p}<0.1$.

S o u r c e : author's regression based upon the Great Intelligence Database in China, using stata 14.0.

To get net effect of mandatory dividend on experimental group and controlling group, the study adopts difference-in-difference model to estimate average difference of agency cost for the above group separately, the result is shown in table 8. From Table 8, we can see that the average agency cost of the control group is 0.134 , and that of the experimental group is 0.154 . The difference is 0.019 , which shows that there is a significant difference between the two groups at the $1 \%$ level. The agency cost of the experimental group is higher. However, after the introduction of mandatory dividend policy, the average agency cost of the experimental group was 0.156 , while that of the control group increased to 0.15 . At this time, the average agency cost of the experimental group is almost the same as that of the control group, which shows that 
the mandatory dividend policy significantly reduces the agency cost of "Iron Cock" company by improving the corporate governance level. Finally, the result of double difference is -0.013 (significant at $1 \%$ ). Thus, the mandatory dividend policy reduced the average agency cost of the experimental group by $1.3 \% \mathrm{com}$ pared with the control group. Therefore, hypothesis 2 is proved.

Table 8. DID result of mandatory dividend and agency cost

\begin{tabular}{|c|c|c|c|c|c|c|c|}
\hline \hline \multirow{2}{*}{ Variable } & \multicolumn{3}{|c|}{ Time 0 } & \multicolumn{3}{c|}{ Time 1 } & \multirow{2}{*}{ DID } \\
\cline { 2 - 7 } & $\begin{array}{c}\text { Control } \\
\text { Group }\end{array}$ & $\begin{array}{c}\text { Experiement } \\
\text { Group }\end{array}$ & Difference & $\begin{array}{c}\text { Controlling } \\
\text { Group }\end{array}$ & $\begin{array}{c}\text { Experiement } \\
\text { Group }\end{array}$ & Difference & \\
\hline Agency Cost & 0.134 & 0.154 & $\begin{array}{c}0.019^{* * *} \\
(8.12)\end{array}$ & 0.150 & 0.156 & $\begin{array}{c}0.006^{* * *} \\
(4.89)\end{array}$ & $\begin{array}{c}-0.013^{* * *} \\
(4.57)\end{array}$ \\
\hline \hline
\end{tabular}

Note: Standard errors in parentheses. ${ }^{* * *} \mathrm{p}<0.01,{ }^{* *} \mathrm{p}<0.05,{ }^{*} \mathrm{p}<0.1$.

S o u r c e : author's regression based upon the Great Intelligence Database in China, using stata 14.0.

\section{Mandatory Dividend Policy and Agency Cost:}

\section{Re-test Based on Dividend Payment Rate and Plate Difference}

In order to obtain more in-depth suppression of mandatory dividend policy on agency costs of enterprises with different dividend levels and different sectors. This paper dividends the samples according to the dividend payment criteria of micro-dividend companies and listed companies. The regression results of the specific grouping DID are shown in table 9.

Table 9. DID Subgroup for mandatory dividend and agency cost

\begin{tabular}{|l|c|c|c|c|c|c|c|c|}
\hline \hline & \multicolumn{2}{|c|}{$\begin{array}{c}\text { Micro Dividend } \\
\text { Company }\end{array}$} & \multicolumn{2}{c|}{$\begin{array}{c}\text { Policy Dividend } \\
\text { Company }\end{array}$} & \multicolumn{2}{c|}{$\begin{array}{c}\text { Small and Medium } \\
\text { Board Company }\end{array}$} & \multicolumn{2}{c|}{ Main Board Company } \\
\cline { 2 - 9 } & $\begin{array}{c}\text { Before } \\
\text { the policy }\end{array}$ & $\begin{array}{c}\text { After } \\
\text { the policy }\end{array}$ & $\begin{array}{c}\text { Before } \\
\text { the policy }\end{array}$ & $\begin{array}{c}\text { After } \\
\text { the policy }\end{array}$ & $\begin{array}{c}\text { Before } \\
\text { the policy }\end{array}$ & $\begin{array}{c}\text { After } \\
\text { the policy }\end{array}$ & $\begin{array}{c}\text { Before } \\
\text { the policy }\end{array}$ & $\begin{array}{c}\text { After } \\
\text { the policy }\end{array}$ \\
\hline \hline $\begin{array}{l}\text { Controlling } \\
\text { Group }\end{array}$ & 360 & 492 & 5781 & 9820 & 1767 & 3549 & 3864 & 5073 \\
\hline $\begin{array}{l}\text { Experimental } \\
\text { Group }\end{array}$ & 22 & 183 & 1323 & 4818 & 107 & 884 & 1209 & 2846 \\
\hline Total & 382 & 675 & 7104 & 14638 & 1874 & 4433 & 5073 & 7919 \\
\hline \hline
\end{tabular}

S o u r c e : author's regression based upon the Great Intelligence Database in China, using stata 14.0. 
From the perspective of dividend payment rate, this paper observes the restraining effect of policy on agency cost. Through the table 10 (2) and (3), we can find that the double difference of agency cost of normal dividend company is -0.013 ( $1 \%$ level is significant), which shows that the mandatory dividend policy can reduce the agency cost of normal dividend company very well. The economic logic behind it: For the cash dividend distribution according to the requirements and the specific situation of the company, we can reduce the disposable cash flow of the enterprise, thereby reducing agency costs and improving corporate governance mechanism. However, for micro-dividend companies, the double difference is - 0.003 (not significant), and there is a "regulatory paradox" with countermeasures under the policy. Since listed companies dare not openly antagonize the SFC, the company will have to submit, but the mandatory dividend policy seriously violates the company's willingness to pay dividends, so the company will adopt a policy of passive resistance, that is, the mandatory dividend-sharing causes listed companies to choose a dividend per share that tends to zero, so that the regulatory authorities will not say a word. However, the cash dividend payment rate is less than 0.1, which is similar to no dividend, so it will not have any impact on the free cash flow of enterprises. Therefore, for micro-dividend companies, the mandatory dividend policy does not reduce the agency costs of such enterprises, so hypothesis 3 is proved.

Secondly, it examines the effect of policies on agency costs from different sectors. The results of grouping DID in different sectors are as shown in table 11. The mandatory dividend policy has better effect on restraining agency costs of listed companies on the motherboard, but has no significant effect on small and medium-sized boards. The main reason is that the company listed on the motherboard has been established for a long time, mainly by stateowned enterprises, and the agency cost is more serious than that of small and medium-sized boards. Therefore, the effect of mandatory dividend policy to reduce the agency cost of listed companies on the motherboard is remarkable. For SMEs listed companies, most of them are in the growth of enterprise life cycle. At this time, it is important to maintain the internal retained earnings and keep the momentum of development, rather than to give back to investors. Therefore, the restraint of mandatory dividend policy on agency costs of SMEs listed companies is not significant. 
Table 10. DID Result about mandatory dividend effect agency cost from the perspective of dividend level and boards

\begin{tabular}{|l|c|c|c|c|}
\hline \hline & Micro dividend & Normal Dividend & Main Board & SME Board \\
\hline \hline Agency Cost & 0.003 & $-0.013^{* * *}$ & $-0.009 * * *$ & $(2.75)$ \\
& $(0.21)$ & $(4.52)$ & $\begin{array}{c}0.001 \\
(0.22)\end{array}$ \\
\hline \hline
\end{tabular}

Note: Standard errors in parentheses. ${ }^{* * *} \mathrm{p}<0.01,{ }^{* *} \mathrm{p}<0.05,{ }^{*} \mathrm{p}<0.1$.

S o u r c e : author's regression based upon the Great Intelligence Database in China, using stata 14.0.

In short, through the heterogeneity analysis of enterprises, we can know that the mandatory dividend policy has better effect on reducing agency costs for listed companies on the motherboard and those with normal dividends, but it has no significant effect on restraining agency costs for listed companies with micro-dividends and small and medium-sized boards.

\section{Mandatory Dividend Policy and Agency Cost: An Analysis of Mediation Effect}

This paper holds that the return rate of total assets of enterprises is the intermediary index of reducing agency cost by mandatory dividend policy. Specifically, in order to achieve a long-term stable dividend target, executives have to work hard and look for high-yield investment projects, that is, executives will work hard so that the company can achieve profitability and continuously improve the dividend level, thereby improving the returns of shareholders and executives. In this way, not only investors 'cash dividends are guaranteed, but also in order to provide cash flow for cash dividends, company executives have to work hard, so the company's total asset return rate will increase. Increasing returns on total assets will be paid to shareholders in the form of cash dividends, not all of which will be translated into private gains of executives. Therefore, mandatory dividend policy can partly mediate agency costs of Iron Cock Company through total assets returns.

To test the intermediary effect of the return on total assets of an enterprise, the study designs Model (16)-(18) to investigate the Mediating Role of Testing Return Rate of Total Assets

$$
\text { agent }_{i t}=\alpha+\beta_{1} \text { treat }^{*} \text { law }_{i t}+\beta_{2} \text { treat }_{i t}+\beta_{3} \text { law }_{i t}+\sum \text { control }_{i t}+\varepsilon_{i t}
$$




$$
\begin{aligned}
& \text { roa }_{i t}=\alpha+\beta_{4} \text { treat } * \text { law }_{i t}+\beta_{2} \text { treat }_{i t}+\beta_{3} \text { law }_{i t}+\sum \text { control }_{i t}+\varepsilon_{i t} \\
& \text { agent }_{i t}=\alpha+\beta_{5} \text { roa }_{i t}+\gamma_{1} \text { treat } * \text { law }_{i t}+\beta_{2} \text { treat }_{i t}+\beta_{3} \text { law }_{i t}+ \\
& \sum \text { control }_{i t}+\varepsilon_{i t}
\end{aligned}
$$

Among them, roa means turnover. According to the test procedure of intermediary effect, model (16) is used to test the effect of mandatory dividend policy on agency cost to see if $\beta_{1}$ is significant. If it is, Model (17) and Model (18) will be tested. Under the condition that $\beta_{4}$ 和 $\beta$ are significant, if $\gamma_{1}$ significant, it shows that the total asset return partly mediates the mandatory dividend policy to restrain agency costs.

Among, roa means turnover.

As shown in table 11, when the agent in column (1) is the explanatory variable, the compulsory dividend policy significantly reduces the agency cost of "iron cock" enterprises. When the agent in the column (2) is the explanatory variable, the compulsory dividend policy significantly reduces the agency cost of the "iron cock" enterprises. When the agent is the explanatory variable in the column (3), the coefficient of law * treatment is still significantly negative after controlling the intermediate variable, indicating that the total return on assets partly mediates the mandatory dividend policy to reduce agency costs. In addition, in order to ensure the reliability of the results, Sobel $\mathrm{Z}$ test is conducted again for the mediation effect. Sobel Z's statistic is -4.329 , which shows that the intermediary effect is significant at the level of $1 \%$. That is to say, the rate of return on total assets of enterprises is indeed an important way to reduce the agency cost of "iron cock" enterprises by mandatory dividend policy.

Table 11. The Mediating Effect of Total Asset Return Rate on Mandatory Dividend

\begin{tabular}{|l|c|c|c|}
\hline \hline \multicolumn{1}{|c|}{ VARIABLES } & Equation(1) & Equation(2) & Equation(3) \\
\hline \hline roa & agent & ROA & $-0.1923^{* * *}$ \\
\hline & & & $(-24.0228)$ \\
\hline Law*treat & $-0.0117^{* * *}$ & $0.0281^{* * *}$ & $-0.0063^{* * *}$ \\
\hline & $(-5.0862)$ & $(14.8830)$ & $(-2.7667)$ \\
\hline treat & $0.0175^{* * *}$ & $-0.0172^{* * *}$ & $0.0142^{* * *}$ \\
\hline & $(8.7498)$ & $(-10.5316)$ & $(7.1654)$ \\
\hline
\end{tabular}


Table 11. The Mediating Effect...

\begin{tabular}{|c|c|c|c|}
\hline & Equation(1) & Equation(2) & Equation(3) \\
\hline VARIABLES & agent & ROA & agent \\
\hline \multirow[t]{2}{*}{ law } & $0.0142 * * *$ & $-0.0366 * * *$ & $0.0072^{* * *}$ \\
\hline & $(5.9801)$ & $(-18.8557)$ & (3.0291) \\
\hline \multirow[t]{2}{*}{ roe } & $-0.0287^{* * *}$ & $0.1141^{* * *}$ & $-0.0068 * * *$ \\
\hline & $(-15.3697)$ & (74.6436) & $(-3.2953)$ \\
\hline \multirow[t]{2}{*}{ lev } & $-0.0902 * * *$ & $-0.0554 * * *$ & $-0.1008^{* * *}$ \\
\hline & $(-33.9950)$ & $(-25.5564)$ & $(-37.9515)$ \\
\hline \multirow[t]{2}{*}{$\operatorname{sh} 1$} & $-0.0448 * * *$ & $0.0255^{* * *}$ & $-0.0399 * * *$ \\
\hline & $(-15.1244)$ & (10.5209) & $(-13.6062)$ \\
\hline \multirow[t]{2}{*}{ bps } & $-0.0023 * * *$ & $-0.0051^{* * *}$ & $-0.0033^{* * *}$ \\
\hline & $(-9.6156)$ & $(-26.0049)$ & $(-13.6759)$ \\
\hline \multirow[t]{2}{*}{ capex } & -0.0061 & $0.0891^{* * *}$ & 0.0111 \\
\hline & $(-0.7018)$ & (12.6207) & $(1.2946)$ \\
\hline \multirow[t]{2}{*}{ sretained } & $-0.0012 * * *$ & $0.0157^{* * *}$ & $0.0018^{* * *}$ \\
\hline & $(-3.1142)$ & (50.1127) & $(4.5806)$ \\
\hline \multirow[t]{2}{*}{ dual } & $0.0091 * * *$ & -0.0003 & $0.0090 * * *$ \\
\hline & (8.5294) & $(-0.3873)$ & (8.5750) \\
\hline \multirow[t]{2}{*}{ cash } & $0.0216 * * *$ & $0.0617^{* * *}$ & $0.0335^{* * *}$ \\
\hline & (5.9857) & (20.8784) & (9.2971) \\
\hline \multirow[t]{2}{*}{ firmage } & $0.0035^{*}$ & $-0.0052 * * *$ & 0.0025 \\
\hline & (1.8419) & $(-3.3584)$ & (1.3299) \\
\hline \multirow[t]{2}{*}{ SOE } & $0.0020 *$ & $-0.0118 * * *$ & -0.0003 \\
\hline & (1.9084) & $(-13.9548)$ & $(-0.2885)$ \\
\hline \multirow[t]{2}{*}{ GEM } & $0.0211^{* * *}$ & 0.0005 & $0.0212^{* * *}$ \\
\hline & (15.5302) & $(0.4644)$ & (15.7994) \\
\hline \multirow[t]{2}{*}{ Constant } & $0.1442 * * *$ & $0.1184^{* * *}$ & $0.1669 * * *$ \\
\hline & (20.2600) & (20.3408) & (23.5409) \\
\hline
\end{tabular}


Table 11. The Mediating Effect...

\begin{tabular}{|l|c|c|c|}
\hline \hline \multicolumn{1}{|c|}{ VARIABLES } & Equation(1) & Equation(2) & Equation(3) \\
\hline \hline $\begin{array}{l}\text { Year } \\
\text { Industry }\end{array}$ & agent & ROA & agent \\
\hline Observations & $\begin{array}{l}\text { Control } \\
\text { Control }\end{array}$ & $\begin{array}{l}\text { Control } \\
\text { Control }\end{array}$ & $\begin{array}{l}\text { Control } \\
\text { Control }\end{array}$ \\
\hline R-squared & 22,799 & 22,799 & 22,799 \\
\hline F & 0.2728 & 0.4202 & 0.2908 \\
\hline
\end{tabular}

Note: Standard errors in parentheses. ${ }^{* * *} \mathrm{p}<0.01,{ }^{* *} \mathrm{p}<0.05,{ }^{*} \mathrm{p}<0.1$.

S o u r c e : author's regression based upon the Great Intelligence Database in China, using stata 14.0.

\section{Robustness Test}

\section{(1) Using Lag Variables}

In order to test the robustness of the conclusion, the least square regression method is used to overcome the endogenous problem in the experimental group and the control group by using the control variable with one lag period. As shown in table 12, the regression results of column (1) and column (2) show that the coefficient of law $*$ treatment is significantly positive at $1 \%$ significance level, which is consistent with the above conclusions. Moreover, because the data span chosen in this paper is from 2007 to 2017, and the data span is large, there may be missing agency cost data. Therefore, this paper chooses deleted data model and uses control variables with a lag of one period to carry out Tobit regression between the experimental group and the control group. Specific results, such as column 11 (3) and column 4 (), show that the coefficient of law * treatment is significantly positive at the $1 \%$ significance level, which is consistent with the above conclusions. Therefore, the conclusion of this paper passes the robustness test. 
Table 12. Robustness Test

\begin{tabular}{|c|c|c|}
\hline & Equation(2) & Equation(4) \\
\hline method & OLS & Tobit \\
\hline \multirow[t]{2}{*}{ Law*treat } & $-0.0083^{* * *}$ & $-0.0077^{* * *}$ \\
\hline & $(-2.7534)$ & $(-2.8779)$ \\
\hline \multirow[t]{2}{*}{ treat } & $0.0165^{* * *}$ & $0.0160 * * *$ \\
\hline & $(6.4080)$ & (6.7749) \\
\hline \multirow[t]{2}{*}{ law } & $0.0045^{*}$ & 0.0030 \\
\hline & (1.8292) & $(1.2130)$ \\
\hline \multirow[t]{2}{*}{ L.roe } & $-0.0345^{* * *}$ & $-0.0342 * * *$ \\
\hline & $(-5.6744)$ & $(-9.5891)$ \\
\hline \multirow[t]{2}{*}{ L.lev } & $-0.0948 * * *$ & $-0.0951^{* * *}$ \\
\hline & $(-27.6810)$ & $(-31.9557)$ \\
\hline \multirow[t]{2}{*}{ L.sh1 } & $-0.0432 * * *$ & $-0.0430 * * *$ \\
\hline & $(-13.5270)$ & $(-13.0720)$ \\
\hline \multirow[t]{2}{*}{ L.bps } & $-0.0022 * * *$ & $-0.0022 * * *$ \\
\hline & $(-7.8117)$ & $(-8.1324)$ \\
\hline \multirow[t]{2}{*}{ L.capex } & 0.0019 & 0.0017 \\
\hline & $(0.2090)$ & $(0.1823)$ \\
\hline \multirow[t]{2}{*}{ L.mglcsy } & $-0.0010^{*}$ & $-0.0012^{* *}$ \\
\hline & $(-1.8598)$ & $(-2.5081)$ \\
\hline \multirow[t]{2}{*}{ L.cash } & $0.0281 * * *$ & $0.0280 * * *$ \\
\hline & (5.7413) & (6.9551) \\
\hline \multirow[t]{2}{*}{ L.firmage } & $0.0045^{* *}$ & $0.0042^{*}$ \\
\hline & $(1.9704)$ & (1.9528) \\
\hline \multirow[t]{2}{*}{ SOE } & 0.0005 & 0.0005 \\
\hline & $(0.4958)$ & $(0.3967)$ \\
\hline \multirow[t]{2}{*}{ GEM } & $0.0193^{* * *}$ & $0.0193^{* * *}$ \\
\hline & (10.5119) & $(12.2623)$ \\
\hline \multirow[t]{2}{*}{ dual } & $0.0099 * * *$ & $0.0099 * * *$ \\
\hline & (7.6190) & (8.2567) \\
\hline
\end{tabular}


Table 12. Robustness...

\begin{tabular}{|c|c|c|}
\hline & Equation(2) & Equation(4) \\
\hline \multirow[t]{2}{*}{ Constant } & $0.1450 * * *$ & $0.1460 * * *$ \\
\hline & $(16.8972)$ & $(18.0257)$ \\
\hline $\begin{array}{l}\text { Industry } \\
\text { Year }\end{array}$ & $\begin{array}{l}\text { Control } \\
\text { Control }\end{array}$ & $\begin{array}{l}\text { Control } \\
\text { Control }\end{array}$ \\
\hline Observa & 19,615 & 19,615 \\
\hline F/ chi2 & 131.7 & 6080 \\
\hline
\end{tabular}

Note: Standard errors in parentheses. ${ }^{* * *} \mathrm{p}<0.01,{ }^{* *} \mathrm{p}<0.05,{ }^{*} \mathrm{p}<0.1$.

S o u r c e : author's regression based upon the Great Intelligence Database in China, using stata 14.0.

\section{(2) Eliminate the Impact of the Financial Crisis}

The subprime mortgage crisis, which began in 2007, will inevitably have an impact on the operation of Listed Companies in China. However, the financial crisis will not only affect listed companies, but also fluctuate investors' investment confidence. Furthermore, investor panic will reduce investors' valuation of listed companies, so the investment and financing of listed companies will be involved, which will also lead to changes in the dividend-sharing strategy of enterprises. Therefore, in order to eliminate the impact of the financial crisis on the conclusions of this study, the data of 2008 and 2009 are excluded and regressed, and the grouping of the two-year samples is excluded as shown in table 13.

Table 13. DID Subgroup

\begin{tabular}{|l|c|c|c|}
\hline \hline & Before Policy & $\begin{array}{c}\text { After } \\
\text { Policy }\end{array}$ & Total \\
\hline \hline Controlling Group & 4051 & 10312 & 14368 \\
\hline Experimental Group & 837 & 5001 & 5838 \\
\hline Total & 4888 & 15313 & \\
\hline
\end{tabular}

S o u r c e : author's regression based upon the Great Intelligence Database in China, using stata 14.0. 
From table 13, we can see that the average agency cost of the control group is 0.134 , the average agency cost of the experimental group is 0.152 , and the difference is 0.018 before the mandatory dividend policy. The difference between the two groups is significant at the level of $1 \%$. The agency cost of the experimental group is higher. However, after the introduction of mandatory dividend policy, the average agency cost of the experimental group was 0.151 , while that of the control group increased to 0.157. At this time, the average agency cost of the experimental group is almost the same as that of the control group. Finally, the result of double difference is -0.011 (significant at $1 \%$ ). Thus, the mandatory dividend policy reduced the average agency cost of the experimental group by $1.3 \%$ compared with the control group. Therefore, it shows that the mandatory dividend policy significantly reduces the agency cost of Iron Cock Company by improving the corporate governance level. This is consistent with the conclusions of this study.

Table 14. DID about mandatory dividend and agency cost

\begin{tabular}{|c|c|c|c|c|c|c|c|}
\hline \hline \multirow{2}{*}{ variable } & \multicolumn{3}{|c|}{ Time 0 } & \multicolumn{3}{c|}{ Time 1 } & \multirow{2}{*}{$\begin{array}{c}\text { Difference- } \\
\text {-in-Difference }\end{array}$} \\
\cline { 2 - 8 } & $\begin{array}{c}\text { Control } \\
\text { Group }\end{array}$ & $\begin{array}{c}\text { Experimental } \\
\text { Group }\end{array}$ & Difference & $\begin{array}{c}\text { Control } \\
\text { Group }\end{array}$ & $\begin{array}{c}\text { Experimental } \\
\text { Group }\end{array}$ & Difference & -in- \\
\hline Agency Cost & 0.134 & 0.152 & $\begin{array}{c}0.018^{* * *} \\
(6.29)\end{array}$ & 0.151 & 0.157 & $\begin{array}{c}0.006^{* * *} \\
(4.80)\end{array}$ & $\begin{array}{c}-0.011^{* * *} \\
(3.59)\end{array}$ \\
\hline \hline
\end{tabular}

Note: Standard errors in parentheses. ${ }^{* * *} \mathrm{p}<0.01,{ }^{* *} \mathrm{p}<0.05,{ }^{*} \mathrm{p}<0.1$.

S o u r c e : author's regression based upon the Great Intelligence Database in China, using stata 14.0.

\section{RESEARCH CONCLUSIONS AND IMPLICATION}

\section{Research Conclusions}

This paper takes Guo Shuqing, the CSCR chairman in November 2011, as the background, and uses the sample of Listed Companies in Shanghai and Shenzhen Stock Exchanges from 2007 to 2017 to study the restraint of mandatory dividend policy on agency costs of enterprises. The hypothesis 1-3 is confirmed by theoretical inference, model analysis and empirical test. To this end, the following specific conclusions can be drawn:

Firstly, mandatory dividend policy will not only undoubtedly increase the willingness of listed companies to pay dividends, but also, more importantly, it 
can significantly restrain the agency costs of listed companies. Specifically, the mandatory dividend policy invisibly increases the expected return of shareholders and potential investors, which can not only motivate them to increase their stock holdings, but also change the balance between supply and demand of the company's stock, thus leading to the rise of stock prices. Obviously, this will ultimately motivate company executives to work harder. At the same time, Executives'due diligence must increase the reward rate of investment projects, which naturally increases cash dividends and cash flow. Therefore, the mandatory dividend policy has constructed a virtuous circle mechanism between senior managers and shareholders, that is, mandatory dividend policy - cash dividend - shareholder ownership - stock price rise - executive hard work the necessary rate of return for investment projects - sufficient cash flow cash dividend payable.

Secondly, the mandatory dividend policy reduces the agency cost of listed companies by changing the total asset return rate. This intermediary effect is completely consistent with the conclusion of the game model, that is, multiple incentives of shareholder ownership, stock price fluctuation and mandatory dividend policy, prompt executives to work hard, improve the expected return on investment projects, and ultimately make the total asset return rate of the company continue to rise, and increase the abundant cash flow for cash dividend. Of course, this will also objectively reduce the agency cost of the company.

Finally, although the mandatory dividend policy reduces the agency cost of Listed Companies in general, the inhibiting effect shows significant heterogeneity, that is, the expected policy effect is unsatisfactory at different levels, and serious deviations have taken place. Specifically, the mandatory dividend policy has a significant inhibitory effect on agency costs of listed companies on the motherboard and normal dividend companies, while for small dividends and small and medium-sized listed companies, the inhibitory effect of agency costs is not significant.

\section{Policy Recommendation}

According to the conclusions of the study, the following suggestions are put forward:

Firstly, since the mandatory dividend policy can suppress the agency cost of Listed Companies in general, it is suggested that the SFC strictly implement the mandatory dividend policy, especially to make clear the punishment measures 
for those who refuse to implement it. In the implementation of the policy, many listed companies secretly display their positions, follow the falsity of the SFC, and passively resist the mandatory dividend policy. This is not only a challenge to the seriousness of the policy itself, but also a disregard and contempt for the rights and interests of small and medium-sized shareholders. Therefore, the CSCR should not only introduce operable policies, but also take strict measures to implement these policies vigorously.

Secondly, considering the heterogeneity of enterprises, it is suggested that the SFC abandon the one-size-fits-all policy and design different dividend standards according to different types of companies. In order to avoid the "regulatory paradox", the SFC should take full account of the growth of listed companies, size and industry differences, and treat them differently, not in a one-size-fits-all manner. That is to say, listed companies with higher agency costs should increase their dividend-sharing ratio, such as state-owned enterprises and state-owned enterprises; for growing enterprises or enterprises with high R\&D investment, the dividend-sharing ratio should be reduced accordingly. At the same time, actively guide listed companies to pay more attention to the protection of the interests of small and medium-sized investors through dividend policy.

Thirdly, in order to avoid the tragic fate of becoming a leek, it is suggested that small and medium-sized investors should actively use the signaling role of cash dividend, dynamically adjust the stock portfolio, consciously vote by foot, and effectively monitor the working attitude and behavior choice of senior managers. After all, a continuous and stable cash dividend is often a signal of the stable financial and operating conditions of listed companies; conversely, the long-term unreasonable non-dividend distribution of listed companies may also be a signal of financial data fraud, internal control and tunneling companies. Therefore, the dividend distribution of listed companies is a good signal to the capital market, and the majority of small and medium-sized shareholders can optimize their stock asset allocation accordingly. At the same time, small and medium-sized shareholders should strive to be close to institutional investors, because institutional investors can monitor the overall operation of enterprises on behalf of small and medium-sized shareholders, and supervise the further improvement of corporate governance.

Fourthly, it is suggested that executives of listed companies should correctly understand the mandatory dividend policy, take this as an opportunity, dividend-sharing according to law, and establish a benign interactive con- 
tractual relationship with shareholders. Since the Company Law determines the obligation of dividend distribution of Listed Companies in the form of law, the dividend distribution of listed companies should be duty-bound. Now the mandatory dividend policy rectifies the long-term non-dividend-sharing of listed companies. Executives should take into account the general situation and strictly implement the mandatory dividend policy.

\section{REFERENCES}

Bao, Y., \& Tianrong, Y. (2014). Intervention of Institutional Investors, Agency Problem and Corporate Dividend. Journal of Shanxi University of Finance and Economics, 36(06), 90-101.

Bao, Y., Wanwei, \& Chow, D. (2018). Cash Dividend Distribution under R\&D Investment Decision: Suppression or Catering. Also on the Paradox of Regulation of "Semi-compulsory Dividend Policy". Journal of Shanxi University of Finance and Economics, 40(03), 94-109.

Bao, Y., \& Tianrong, Y. (2014). Intervention of Institutional Investors, Agency Problem and Corporate Dividend. Journal of Shanxi University of Finance and Economics, 36(06), 90-101.

Changqing, L., Zhihua, W., \& Shinong, W. (2010). Market Response to Semi-compulsory Dividend Policy. Economic Research, 45(03), 144-155.

Genfu, F., \& Juehang, Z. (2012). Manager's Compensation, On-the-job Consumption and Corporate Performance: From the Perspective of Cooperative Game Analysis. China's Industrial Economy, 06, 147-158.

Guojie, Y., \& Yuyu, Z. (2018). Semi-mandatory Dividend Sharing Policy and Earnings Management of Refinancing Enterprises: Evidence from PSM. Journal of Nanjing Audit University, 15(05), 75-85; 93.

Guoling, Q. (2014). Semi-mandatory Dividend Sharing Policy, Adverse Selection and Dividend Tunneling. Investment Research, 33(10), 118-131.

Guoling, Q., Huan, L., \& Ziwei, Z. (2017). The Paradox of Cash Dividend Policy of GEM Listed Companies: An Explanation Based on Dividend Tunneling Theory. China's Economic Issues, 02, 68-79.

Hanming, Y. (2008). Empirical analysis of equity concentration, cash dividend and enterprise value. Financial Economy, 08, 67-72.

Haoran, X., \& Guanmin, L. (2018). The Corporate Governance Function of Dividends: An Empirical Test Based on Compulsory Dividends of Central Enterprises. Journal of Central University of Finance and Economics, 04, 53-62.

Jing, L., \& Debo, J. (2017). Demand for refinancing, regulatory pressure and cash dividend. Audit and Economic Research, 32(02), 88-97.

Juanjuan, H., \& Yifeng, S. (2007). Who does the dividend policy of listed companies cater to? Empirical data from Chinese listed companies. Accounting research, 08, 36$-43 ; 95$. 
Lili, Z. (2018). The Role of Major Shareholders in Directional Additional Issuance and Acquisition: Support or Benefit Transfer: An Empirical Study Based on the Merger and Acquisition of Non-listed Companies by Listed Companies. Journal of Shanxi University of Finance and Economics, 40(07), 82-97.

Modigliani, F., \& Miller, M.H. (1961). Dividend policy, growth, and the valuation of shares. Journal of Business, 34(4), 411-433.

Qingsong, A. (2012). Study on the Present Situation and Trend of Dividend Sharing of Chinese Listed Companies. Stock Market Report, 11, 15-19.

Tao, Z., \& Deyou, W. (2007). Cash Dividend: Mitigating Agency Problem or Major Shareholder Exploitation: A Study from the Perspective of Final Ownership Structure. Journal of Shanxi University of Finance and Economics, 08, 97-102.

Xing, L., Weirong, T., \& Ning, L. (2016). Semi-mandatory Dividend Policy, Cor porate Governance and Cash Dividend Policy. Nankai Management Review, 19(05), 104-114.

Yaoting, H., \& Mahong (2017). Agency Cost, Semi-mandatory Dividend and Corporate Value: Empirical Evidence from Chinese A-share Listed Companies. Journal of Guizhou University of Finance and Economics, (04),76-83.

Yan, C., Xin, L., \& Mengshun, L. (2015). Research on the Effectiveness of Semi-mandatory Dividend Policy from the Perspective of Cash Dividend Catering, Refinancing Demand and Enterprise Investment-Investment Efficiency. Accounting Research, 11, 69-75; 97.

Yan, Y., \& Chunfei, W. (2014). Economic consequences and potential problems associated with refinancing and dividend policy. China Accounting Review, 12(01), 43-66.

Yi, Y., \& Yifeng, S. (2004). Cash Dividend: Transferring Profit Signal or Supervising Governance Function. China Accounting Review, 01, 61-76.

Yinguo, L. (2008). An Empirical Study on Dividend Policy Effectiveness of Listed Companies in China. Economic Management, 14, 26-33.

Yinguo, L., Chen, Z., \& Sumei, R. (2014). Research on the Effect of Agency Cost Control of Cash Dividend Based on Semi-mandatory Dividend Sharing. Audit and Economic Research, 29(05), 59-68.

Yunling, C. (2014). Study on the Implementation Effect of Semi-compulsory Dividend Policy. Financial Research, 08, 162-177.

Yinguo, L., Chen, Z., \& Sumei, R. (2014). Research on agency cost control effect of cash dividend based on semi-mandatory dividend distribution. Audit and economic research, 29(05), 59-68.

Yong, S., \& Sihao, L. (2018). Research on Related Party Transactions, Heterogeneity of Institutional Investors and Risk of Stock Market Crash. China Soft Science, 04, 123-131.

Zhihua, W., Yuhui, W., \& Changqing, L. (2012). Institutional Investor Ownership and Cash Dividend Policy of Chinese Listed Companies. Stock Market Report, 10, 40-47; 60.

Zhihua, W., Maoliang, L., \& Changqing, L. (2014). Semi-compulsory Dividend policy and Dividend-sharing Behavior of Chinese Listed Companies. Economic Research, 49(06), 100-114.

Zhihua, W., Changqing, L., Yuhui, W., \& Jiajia, H. (2017). Semi-mandatory policy, refinancing motivation and classical dividend theory: Empirical research based on dividend agency theory and signal theory. Accounting Research, 07, 55-61; 97. 
Zhiqiang, W., \& Weiting, Z. (2012). Financial flexibility, refinancing options and dividend catering strategies of listed companies. Management World, 07, 151-163.

Zuoping, X., \& Zhongqin, S. (2012). Is cash dividend a tool of "tunneling" or a mask of "tunneling"? Empirical evidence from Chinese listed companies. Journal of Management Engineering, 26(02), 77-84. 